\title{
Objects as battlefields in the struggle for civil rights: The archaeology and analysis of contemporary material culture and heritage in Chile
}

\author{
Dafna GOLDSCHMIDT LEVINSKY \\ (2ARQUEOLOGIAHISTORICASANTIAGO \\ dafna_g@hotmail.com \\ Javiera LETELIER COSMELLI \\ Universidad Austral de Chile \\ javieraletelier@gmail.com
}

On October 18, 2019, Chile joined a local and global phenomenon, when a popular movement exploded following student protests over an increase in public transportation fares in Santiago, the capital. Since that day, the streets have been home to public defiance of the foundations of neoliberalism. The neoliberal system was established during the dictatorship of Augusto Pinochet, and has intensified in the subsequent years of democracy, fomenting economic and social inequity.

In Chile's case, this social phenomenon, dubbed by the people as Revuelta (Revolt), Estallido (Eruption), or Despertar Social (Social Awakening), has a material correlate, analyses of which allow us to place ourselves within the social, political, and cultural dynamics that are playing out in the streets. In the trash bins on main streets, popular protests and subsequent police repression are reflected in the remains of spoons and pots from so-called cacerolazos. These kitchen implements took on a new significance as instruments of protest, ${ }^{1}$ joining other objects in the trash, including the small bullets and tear gas canisters that the police use on a daily basis to repress the protesters.

1 Cacerolazo: A manner of protesting that consists of banging a pot or pan with a spoon (typically made of wood) or other object. The origin of this style of protest is unclear, but in Chile it can be traced back at least to the Marcha de la Cacerolas Vacias (March of the Empty Pots) in 1971 (Crummett 1977). It originated with women's groups protesting Popular Unity's leftist government, using domestic objects related to food to signify the lack of food (Matterlat 1975, Crummett 1977). Later, the cacerolazo was repurposed to be used against the dictatorship (Telechea 2006). This type of protest also has been documented in other countries, including Argentina and Colombia (Telechea 2006, Equipo Jurídico Pueblos 2020).

\section{AP: Online Journal in Public Archaeology - Volume 11 - ISSN: 2171-6315}

Goldschmidt Levinsky, D \& Letelier Cosmelli, J. 2021. Objects as Battlefields in the struggle for civil rights: the archaeology and analysis of contemporary material culture and heritage in Chile. AP: Online Journal in Public Archaeology 11, y1-y5. DOI: 10.23914/ap.v11i0.288 


\section{y2 :: AP Journal v.11 :: POINTS OF YOU}

Although these objects usually are considered trash, their value is being recognized. The public has raised them up in acts of remembrance and resistance to memorialize the cost of police repression since October $18,{ }^{2}$ with such items inviting a contemporaneous archaeological analysis.

As another form of protest that has gained popularity, graffiti of diverse slogans related to the protesters' demands cover the city's walls and monuments. Depending on their location, the graffiti are constantly painted over by local political authorities, generating a symbolic struggle of painting and repainting, a stratigraphy that reflects the conflict between the protesters' demands and the prevailing political system.

This tension has been demonstrated explicitly on several national monuments in Chile. For example, a number of very old churches have been set on fire, and statues of conquerors and military heroes have been damaged and even removed from public spaces by protesters. One of the most emblematic cases of late involved a monument to General Manuel Baquedano located in Baquedano Plaza, popularly known today as Dignity Plaza, the epicenter of the social protests.

The monument to General Baquedano itself is a battlefield, pitting different aspects of traditional ideas against each other. Baquedano participated in Chile's northern and southern expansion in the nineteenth century, leaving thousands dead, principally Mapuche people and rank-and-file soldiers. ${ }^{3}$ Considering this history, the protests around this monument represent an active societal examination of the country's historical debt to its native people and its workers.

An example of this reckoning was the installation across from Dignity Plaza of rewes (Mapuche altars), which bear great importance within the Mapuche community. The rewes were removed during one of the constant monument "cleanings", while the monument to General Baquedano remains in place, its multiple layers of paint laid one over another as testimonials to the opposing bands of protesters and state power seeking to preserve hegemonic ideas of cultural heritage ${ }^{4}$.

At the same time, the monument has relevance not only due to whom it represents, but also primarily due to its location in Dignity Plaza, which historically has been the site of social protests (Orozco 2018), particularly after the return to democratic government in 1990. Dignity Plaza also has become the landmark

2 https://villagrimaldi.cl/noticias/exposicion-de-fotografia-y-objetos-de-la-actual-revuelta-social-y-politicachilena-se-exhibira-en-sitio-de-memoria-parque-por-la-paz-villa-grimaldi/

3 Baquedano participated in the state-sponsored Campaign to Pacify the Araucanía from 1862 to 1883, which sought to extend the country's southern border and reduce the indigenous population.

4 The monument to General Manuel Baquedano was removed on March 12th 2021 for conservation and security reasons, according to the Consejo de Monumentos Nacionales (CMN), the state institution that cares about national heritage. A metal wall was installed around the statue's pedestal. 
that geographically and symbolically separates the lower and middle classes from the upper class in a highly segregated city.

All of this material evidence leads us to question the role archaeology has played in perpetuating a hegemonic vision of the past, which in Chile has been built upon official history that highlights republican milestones since the nineteenth century and obscures much of the existing cultural diversity. Traditionally, this has left archaeologists to consider only some of this diversity, limited to the study of those societies in existence prior to the arrival of Europeans in America, disconnected from current society and relegated to the notion of distant past or "prehistory".

For this reason, we believe it is vital to reframe and redefine certain concepts that we use daily in our discipline, such as those of prehistory or historical archaeology. To endorse archaeology that relies on colonial and republican milestones as "history" means to continue denying and delegitimizing the history that predates the arrival of the Spanish, with peculiar, out-of-date processes that often eclipse or minimize the monumental archaeology of the Mayas, Aztecs, and Incas and that reinforce Western imperialist ideas. As such, in the context of the time in which we are living, we must be conscious of the term "historical archaeology" as a colonial concept.

As professionals in the area of archaeology and cultural heritage, we have witnessed how quickly social change mixes with material culture, in a constant interaction and tension across society, objects and space. In this way, material culture can be understood as a historical source (Hicks 2003). No longer simply a piece of the past, material culture is part of society, and therefore also part of modernity and post-modernity. It is in this context that material culture can be understood as "the social life of things" (Schávelzon 2002 p. 201).

This leads to a series of questions about how to include the public in determining what is recognized as cultural heritage and what is not, particularly with the understanding that archaeology regulates itself through scientific articles written in technical and inaccessible language. These scientific publications often are supported by public funding, yet remain exclusively within the same academic circles.

Additional questions arise about how we have recognized different communities and integrated them into history, and the value judgements inherent in that process, since our work offen focuses on the past of others. This provokes other questions about how to avoid falling into indifference or condescension, and how archaeology can assume its role in revealing the diverse social spectrum beyond dominant binary concepts, including aspects of social class, ethnic diversity, age ranges, and gender identity, among others. 


\section{y4 :: AP Journal v.11 :: POINTS OF YOU}

In recent years, archaeology has been evolving, thanks to the development of diverse approaches. Postcolonial approaches and intersectional studies performed through a gender lens, like queer/cuir theory, have given rise to challenges to the construction of the past. However, these remain the exception. Archaeology is relevant as a tool by which to analyze contemporary society in relation to its material and spatial perspectives, whose meaning varies depending not only on the time period, but also their social context. In this way, analyzing contemporary material culture, and the protests in particular, allows us to bring ourselves close to the various social movements of recognition and resistance, and leads us to challenge ourselves about archaeology's social responsibility.

Acknowledging our lack of clarity and contradictions, which have been amplified by new approaches to material culture related to social movements for civil rights, above all (since October 18 in Chile's case), and in the context of a pandemic that has raised more questions than answers, we believe it is imperative to reexamine certain concepts we employ, and all the perspectives and interpretations of our monuments and material culture in general, as well as the value judgments involved and our role in that process.

\section{Acknowledgments}

Special thanks to Patricia Julianelle, Amalia Nuevo Delaunay and Lucas Gutiérrez Lafrentz.

\section{References}

Crummett, M. 1977. El Poder Femenino: the Mobilization of Women Against Socialism in Chile. Latin American Perspectives 4(4), 103 113. doi:10.1177/0094582x7700400407

Equipo Jurídico Pueblos 2020. Esbozo de una radiografía política del paro en Colombia. Revista CEPA 30, 28-32.

Hicks, D. 2003. Archaeology unfolding: Diversity and the loss of isolation. Oxford Journal of Archaeology 22, 315-29.

Mattelart, M. 1975. Chile: The Feminine When Bourgeois Women Side of the Coup or Take to the Streets. NACLA's Latin America and Empire Report, 9 (6), 14-25. doi: 10.1080/10714839.1975.11724011

Orozco, K. 2018. El Patrimonio cultural inmaterial de la Plaza Baquedano en Santiago de Chile. Territorio en Formación [S.I.] 14, 74-94. doi: 0.20868/ tf.2019.14.3893

Schávelzón, D. 2002. El futuro del pasado: Indagaciones en arqueología urbana. In Alderoqui, S. and Penchansky, P. (eds.), Ciudad y Ciudadanos: Aportes para 
:: Goldschmidt \& Letelier - Points of You: Objects as battlefields... :: y5

la enseñanza del mundo urbano. Cuestiones de Educación 36. Buenos Aires, Editorial Paidos, 199-215.

Telechea, R. 2006. Historia de los cacerolazos: 1982- 2001. Razón y Revolución $16,141-184$.

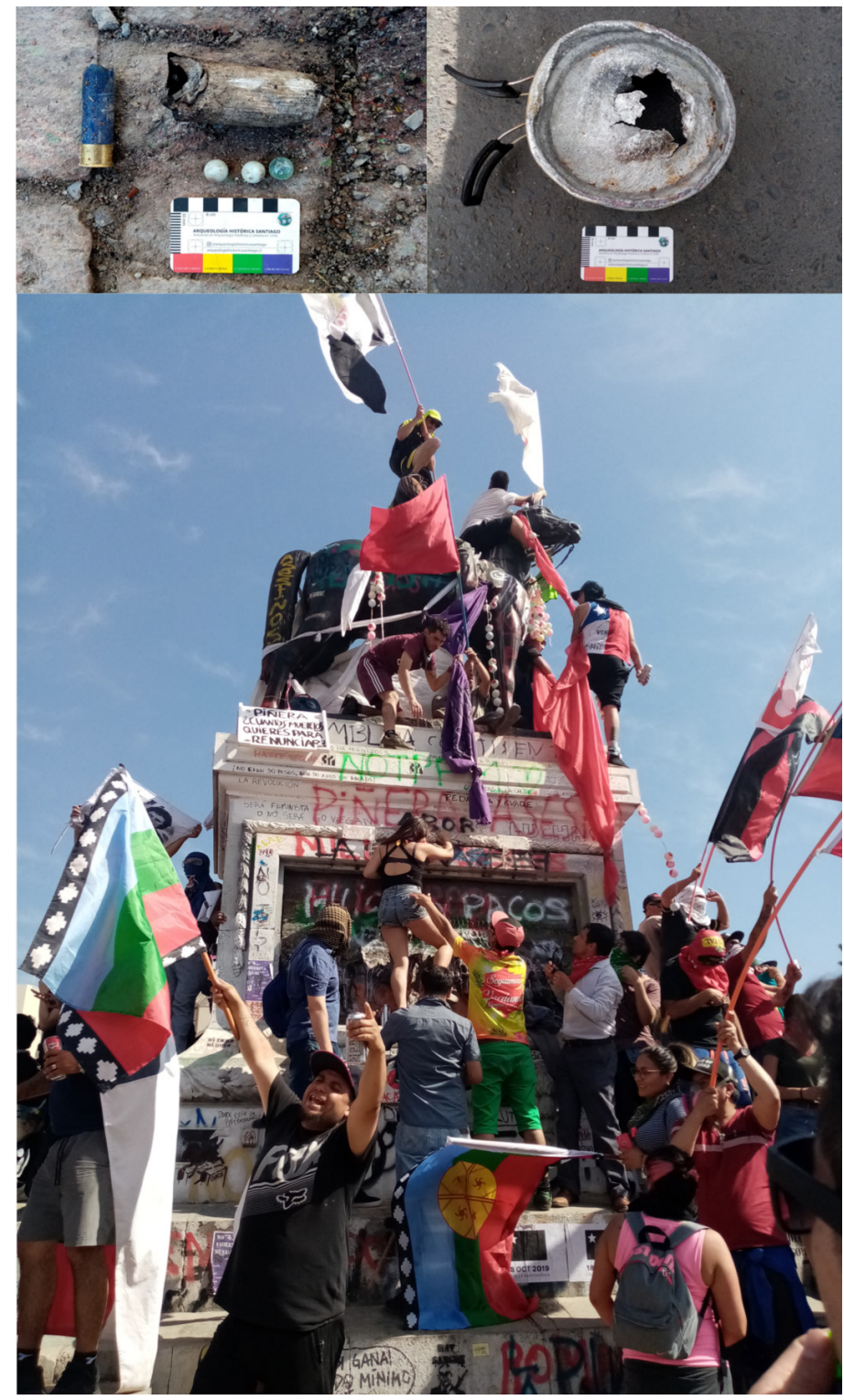

Figs.: Rubber shot cartridges and tear gas canisters used for repression. Marbles used by protesters against the police; Pot discarded as trash on the floor, remnant of a cacerolazo protest; Monument to General Baquedano during the protest. 
